\title{
Article
}

\section{Water quality of Barishal sadar upazila in Bangladesh for drinking, irrigation, aquaculture and livestock consumption}

\author{
Md. Imdadul Hoque ${ }^{1 *}$, Md. Aktarul Islam ${ }^{1}$ and Md. Niaz Morshed ${ }^{2}$ \\ ${ }^{1}$ Bangladesh Institute of Nuclear Agriculture, Mymensingh, Bangladesh \\ ${ }^{2}$ Bangladesh Sugarcrop Research Institute, Sub-station Barishal, Bangladesh \\ *Corresponding author: Md. Imdadul Hoque, Scientific Officer, Bangladesh Institute of Nuclear Agriculture, \\ Mymensingh, Bangladesh. E-mail: apu.pstu@gmail.com
}

Received: 03 February 2020/Accepted: 24 March 2020/ Published: 31 March 2020

\begin{abstract}
A study was conducted to assess of groundwater and surface water quality of Barisal sadar upazila. Total 22 water samples (11 pond water and 11 groundwater) were collected from January to March, 2017. Samples were slightly acidic in nature and 7 pond water not suitable for aquaculture in respect of $\mathrm{pH}$. Samples of pond were "excellent" and groundwater samples were "good" for irrigation except two high salinity group water for irrigation for EC. Calcium indicates the samples were suitable for aquaculture but 7 samples were not suitable due to higher $\mathrm{Mg}$ content. In respect of $\mathrm{K}, 9$ samples were not suitable for aquaculture. $\mathrm{Cu}$ concentrations found suitable for all purposes. For $\mathrm{Fe}$ and $\mathrm{Zn}$ samples are suitable for irrigation and consumption. Chloride showed, samples were not suitable for livestock consumption except 7 ponds sample. Samples are not suitable for aquaculture in respect of $\mathrm{Cl}, \mathrm{Fe}$ and $\mathrm{Zn}$. For Manganese, samples (except 1) found suitable for consumption. Samples were "excellent" for sensitive, semi-tolerant and tolerant crops in respect of B. Not any samples responded to $\mathrm{CO}_{3}$ test and $\mathrm{HCO}_{3}$ concentrations found normal. All water sources free from Arsenic contamination. Phosphorus concentration in groundwater might not be harmful for multipurpose use. SAR categorized all samples "excellent" class for irrigation except 2 groundwater samples. 15 samples were "suitable", 3 were "marginal" and 4 were "unsuitable" for irrigation in respect of RSC. For $\mathrm{H}_{\mathrm{T}}, 13$ were "moderately hard" and 09 were "hard" limit for irrigation and samples were suitable for drinking and livestock consumption.
\end{abstract}

Keywords: drinking water; irrigation water; aquaculture; livestock; surface water; groundwater

\section{Introduction}

Quality water is a great challenge for $21^{\text {st }}$ century and is more essential than its quantity. Water quality is deteriorated day by day due to numerous of biological, physical and chemical variables causing water toxicity. Water is a universal solvent and various types of elements are dissolved in it, but the concentration of any element or compound beyond tolerance limit for organisms and other usage, treated as pollutants. We have plenty of both surface and ground water supply to support the entire population in Bangladesh. In fact, after human resources water is the most abundant resource in Bangladesh (Azad, 2003).

The most important use of water in agriculture is for irrigation, which is a key component to produce enough food. Irrigation takes up to $90 \%$ of water withdrawn in some developing countries and significant proportions in more economically developed countries (United States, 30\% of freshwater usage is for irrigation). Yet even on the same continent, water used for irrigation in Spain, Portugal and Greece exceeds $70 \%$ of total usage.

The human body contains from $55 \%$ to $78 \%$ water, depending on body size. To function properly, the body requires eight glasses of water per day to avoid dehydration; the precise amount depends on the level of activity, temperature, humidity, and other factors. 
Besides the agricultural use, surface water is equally important for aquaculture usage. Waterborne toxic chemicals pose the greatest threat to aquatic environment. The toxic chemicals adversely affect the production of fish in water system (Lloyd, 1992). Aquaculture can play a major role in delivering high quality, energy and protein rich foods to the world's poor, in economic development, and overall poverty alleviation. Eight percent of the world's water is used for livestock production.

Among soluble constituents in water, common major and secondary constituents are $\mathrm{Ca}, \mathrm{Mg}, \mathrm{Na}, \mathrm{Fe}, \mathrm{B}, \mathrm{MO}_{3}$, $\mathrm{HCO}_{3}, \mathrm{SO}_{4}$, and $\mathrm{Cl}$ but minor or trace constituent are $\mathrm{As}, \mathrm{Cd}, \mathrm{Cr} . \mathrm{Cu}, \mathrm{Mn}, \mathrm{P}$ and $\mathrm{Zn}$ (Davis and Weist, 1966). Contaminated water directly affects the health of inhabitants, fish resources flora and fauna. Pollution and contamination of the rivers, water has impacts on the aquatic resources. When water is polluted with highly concentrated heavy metals then more people will die from the water home diseases including diarohoea, cholera, jaundice, hepatitis, dysentery, skin diseases etc.

In the study areas, farmers are frequently using surface water for irrigation and aquaculture purposes, and groundwater for drinking and in some cases irrigation. Considering the above points, the research was conducted to evaluate the chemical quality and suitability of water for drinking, irrigation, aquaculture and livestock consumption.

\section{Materials and Methods}

Barisal upazila is in southern Bangladesh and located in south-central Bangladesh. It is located in the north part of Bay of Bangle and 15-20 feet height from sea level. Barisal Sadar is located at $22.70000^{\circ} \mathrm{N} 90.3667^{\circ} \mathrm{E}$ is bounded by Babuganj, Muladi and Mehendiganj upazilas on the north, Bakerganj and Nalchity upazila on the south, Mehendiganj and Bhola sadar upazilas on the east, Jhalokathi and Nalchity upazilas on the west. It covers a part of Young Meghna Estuarine Floodplain (AEZ 18). Barisal Sadar Upazila is a central area of Barisal district. There are 10 unions, 41823 households in the sadar upazila. Among the 10 unions 5 are separated by the river kirtonkhola from main land. The area of sadar upazila is $387 \mathrm{sqKm}$. The population of the upazila is 218680 (Population Census-2001). Climate: Typical monsoon climate with maximum $33.3^{\circ} \mathrm{C}$ and minimum $12.1^{\circ} \mathrm{C}$; annual rainfall $2506 \mathrm{~mm}(1997)$.

Eleven pond water and eleven ground water samples were collected from the different locations of Barisal sadar upazila in Bangladesh which cover a part of Young Meghna Estuarine Floodplain (AEZ 18). The samples were collected during January to March, 2017 following techniques outlined by Hunt and Wilson (1986) and APHA (2005). All the samples were collected in $0.5 \mathrm{~L}$ clean plastic bottle previously washed with diluted hydrochloric acid (1:1) followed by distilled water and was sealed immediately to avoid air exposure. During sampling, all the waters were colorless, odorless, tasteless and also free from turbidity. The chemical analyses were performed at the laboratory of soil Science, Agricultural Chemistry Department, Prof. Mohammad Hossain central laboratory of Bangladesh Agricultural University and Soil science laboratory of Bangladesh Institute of Nuclear Agriculture (BINA). The pH was determined following method mentioned by Eaton et al. (1995), EC and TDS were by Tandon (1995). $\mathrm{CO}_{3}$ and $\mathrm{HCO}_{3}$ were determined acidimetrically and argentometric titration was followed for the determination of $\mathrm{Cl}$ after Eaton et al. (1995). Ca and $\mathrm{Mg}$ were determined by complexometric method of titration Page et al. (1982). Na and K were determined by flame photometrically following method outlined by Gosh et al. (1983). $\mathrm{Zn}, \mathrm{Cu}, \mathrm{Fe}, \mathrm{Mn}$ and As were determined by atomic absorption spectrophotometer (AAS) outlined by Eaton et al. (1995). P was determined colorimatrically by stannous chloride method stated by APHA (1995). B was determined by Azomethine-H method following the instructions of Page et al. (1982). Sodium Adsorption Ratio (SAR), Soluble Sodium Percentage (SSP), Residual Sodium Carbonate (RSC) and Hardness $\left(\mathrm{H}_{\mathrm{T}}\right)$ were calculated following standard formula mentioned by Mishra and Ahmed (1993), Richards (1968) and Michael (1997). The statistical analyses of the analytical results obtained from water samples were performed (Gomez and Gomez, 1984) with the help of computer package M-STAT.

\section{Results and Discussion}

\section{1.pH}

The $\mathrm{pH}$ of the pond and groundwater samples ranged from 6.23 to 7.21 and 6.10 to 7.08 respectively, with the mean value of 6.60 and 6.60. The respective standard deviations (SD) were 0.35 and 0.30 . The \% co-efficient of variation was5.34 and 4.61 (Table 1). All of the waters were slightly acidic in nature. This result revealed that the pond and tube-well has a great similarity of $\mathrm{pH}$. Water having $\mathrm{pH}$ value less than 6.5 and more than 9.5 is unsuitable for drinking (WHO, 1971). According to this limit 6 pond and 4 groundwater samples had limitation for drinking (Table 2). The recommended $\mathrm{pH}$ for aquaculture is 6.5 to 8.0 (Meade, 1989). Based on this 
recommendation, 7 (sample No. 2, 3, 5,6,8,9 and 10) pond water samples were unsuitable for aquaculture and rest 4 samples were suitable (Table 5).

\subsection{Electrical conductivity (EC)}

The electrical conductivity of the pond and groundwaters varied from 84.60 to 239.00 and 468.00 to 820.00 $\mu \mathrm{Scm}^{-1}$, respectively. The mean, standard deviation and \% co-efficient of variation (CV) were 151.27 and 578.72, 51.01 and 121.76, 33.72 and 21.03, respectively (Table 1). Based on of EC, Richards (1968) classify irrigation water into 4 classes.

According to his classification all the samples of pond were rated as "low salinity" and most of the groundwaters were "medium salinity" (C2) class for irrigationand two are high salinity group (C3) (Table 3). All samples of pond were "excellent" and all the groundwaters were "good" for irrigation except two high salinity group water (Table 3) based on Wilcox (1955).

\subsection{Total dissolved solids (TDS)}

The total dissolved solids present in water samples are very important to assess the suitability of water for drinking, irrigation, aquaculture and livestock consumption. TDS of the samples

ranged from 103.60 to $223.50 \mathrm{mgL}^{-1}$ (pond) and 321.00 to $475.00 \mathrm{mgL}^{-1}$ (groundwater) with the respective mean, SD and CV of 160.80 and 390.27, 37.74 and 43.28, 23.47 and 11.09 (Table 1). According to WHO (1971) and Freeze and Cherry (1979) all the samples were "highest desirable" limit for drinking and "fresh water" for irrigation, respectively (Table 2,3). All the samples were also suitable for aquaculture and livestock based on Meade (1989) and Ayers and Westcot, (1985), respectively. High TDS indicated the presence of sufficient amounts of bicarbonates, sulphates and chlorides of $\mathrm{Ca}, \mathrm{Mg}, \mathrm{Na}$ and $\mathrm{Si}$ (Karanth, 1994).

\subsection{Calcium (Ca)}

Calcium concentration of the samples fluctuated from 9.61 to $32.06 \mathrm{mgL}^{-1}$ (pond) and 16.06 to $30.46 \mathrm{mgL}^{-1}$ (groundwater). The respective mean, SD and CV of pond and groundwater were 22.73 and 24.33, 7.64 and $4.46,33.65$ and 18.36, respectively (Table 1). Irrigation water containing less than $100 \mathrm{mgL}^{-1} \mathrm{Ca}$ is "suitable" for raising crop plants (Todd, 1980). WHO (1971) reported that the highest desirable and maximum permissible limit of Ca for drinking is 0.75 and $200.00 \mathrm{mgL}^{-1}$, respectively. According to this recommendation all the water samples were in "maximum permissible" limit for drinking (Table 2). Meade (1989) recommended that Ca status of aquaculture water should be ranged within 4 to $160 \mathrm{mgL}^{-1}$, according to his range all the samples were "suitable" for aquaculture (Table 4).

\subsection{Magnesium (Mg)}

The concentration of magnesium of pond and groundwater varied from 3.89 to 34.04 and 6.08 to 32.09 , with the mean value of 19.45 and $21.48 \mathrm{mgL}^{-1}$, respectively. The CV and SD were 52.73 and 35.90, 10.25 and 7.71, respectively (Table 1). According to WHO (1971) the entire samples were within "highest desirable" class except 1 groundwater (sample No. 05) were "maximum permissible" for drinking (Table 2). According to Meade (1989) the $\mathrm{Mg}$ concentration for aquaculture is $<15 \mathrm{mg} \mathrm{L}^{-1}$, based on this 7 samples (No. 2, 3, 5, 6, 8, 10 and 11) were not suitable for aquaculture (Table 5).

\subsection{Sodium (Na)}

Sodium values of pond and groundwater ranged from 5.73 to 34.92 and 12.22 to $21.54 \mathrm{mgL}^{-1}$, respectively. The mean value of $17.89 \mathrm{mgL}^{-1}$ (pond) and $17.63 \mathrm{mgL}^{-1}$ (groundwater). The respective SD and CV were 8.77 and 3.29, 49.03 and 18.71 (Table 1). Sodium in the aquatic system is mainly derived from atmospheric deposition; evaporate dissolution and silicate weathering (Berner and Berner, 1987). According to Ayers and Westcot (1985), irrigation water generally containing less than $40 \mathrm{meL}^{-1} \mathrm{Na}$ is suitable for crops and soils. The detected $\mathrm{Na}$ content in all the water samples under test were far below this specified limit. All the samples of were "suitable" for aquaculture based on Meade, 1989 (Table 4).

\subsection{Potassium (K)}

The concentration of potassium in samples varied from 4.23 to $18.03 \mathrm{mgL}^{-1}$ (pond) and 3.40 to $7.16 \mathrm{mgL}^{-1}$ (groundwater), with the mean value of 9.40 and $4.69 \mathrm{mgL}^{-1}$. The respective CVand SD of pond and groundwater were 49.47 and $26.28,4.65$ and 1.23 (Table 1). The $\mathrm{K}$ concentration limit for aquaculture is $<5$ $\mathrm{mgL}^{-1}$, according to Meade (1989) 2 waters (No. 1 and 10) were suitable and rest 09 were unsuitable for 
aquaculture (Table 4). According to Ayers and Westcot (1985), the recommended limit of $\mathrm{K}$ in irrigation water is $2.0 \mathrm{mgL}^{-1}$. In the investigated area, all of the water samples exceeded the limit.

\subsection{Copper $(\mathrm{Cu})$}

The content of $\mathrm{Cu}$ in pond water was very low $\left(<0.0001 \mathrm{mgL}^{-1}\right)$ and groundwater varied from ND to 0.048 $\mathrm{mgL}^{-1}$. The mean value was $0.01 \mathrm{mgL}^{-1}$. The respective SD and CV were 0.016 and 164.94. WHO (1971) and USEPA (1975) recommended that the $\mathrm{Cu}$ concentration in drinking water should be within 0.05 to 1.5 and $1.0 \mathrm{mgL}^{-1}$ respectively. Therefore, the waters of the study area were within safe limits and suitable for drinking. The samples were also suitable for irrigation, aquaculture and livestock consumption in respect of $\mathrm{Cu}$.

\subsection{Chloride (Cl)}

Chloride contents of the samples ranged from 11.99 to $63.98 \mathrm{mgL}^{-1}$ (pond) and 95.97 to $171.94 \mathrm{mgL}^{-1}$ (groundwater), having mean, CV and SD of pond and groundwater were 29.26 and 116.87, 54.25 and 18.31, 15.87 and 18.31, respectively. Maximum permissible limit of $\mathrm{Cl}$ in drinking water is $4.00 \mathrm{meL}^{-1}\left(141.80 \mathrm{mgL}^{-1}\right)$ as reported by Ayers and Westcot (1985). According to this limit all pond water were permissible limit. The recommended concentration of $\mathrm{Cl}$ for livestock consumption is $30 \mathrm{mgL}^{-1}$ (Ayers and Westcot, 1985). According to their recommendation all groundwater samples were unsuitable for livestock consumption because $\mathrm{Cl}$ values were $>30 \mathrm{mgL}^{-1}$ and 7 ponds water (No. 1, 2, 4, 6, 8, 9 and 11) were suitable (Table 5). Based on Meade (1989) recommendation the samples were also not suitable for aquaculture (Table 4).

\subsection{Iron (Fe)}

The concentration of iron in pond and groundwater samples varied from 56.63 to $144.10 \mu \mathrm{gL}^{-1}$ and 75.08 to 154.22 $\mu \mathrm{gL}^{-1}$, respectively. The mean value was $110.52 \mu \mathrm{gL}^{-1}$ (pond) and $96.30 \mu \mathrm{gL}^{-1}$ (groundwater). The respective $\mathrm{CV}$ and SD were 20.92 and $22.33,23.12$ and 21.50 for pond and groundwater (Table 1). The Fe concentration limit for aquaculture is $<0.01 \mathrm{mgL}^{-1}$, according to Meade (1989) the samples were not suitable for aquaculture (Table 4). The recommended limit of iron for drinking is 0.05 to $1.5 \mathrm{mgL}^{-1}$ and $0.3 \mathrm{mgL}^{-1}$ (WHO, 1971 and USEPA, 1975). Based on this recommendation the samples were suitable for drinking (Table 2). The sample of the study area does not exceed the recommended limit for irrigation and livestock consumption (Table 3,4) according to Ayers and Westcot (1985).

\subsection{Manganese (Mn)}

Manganese content in pond and groundwater ranged from 30.86 to $120.81 \mu \mathrm{gL}^{-1}$ and 33.43 to $46.78 \mu \mathrm{gL}^{-1}$. The mean value was $50.71 \mu \mathrm{gL}^{-1}$ (pond) and $40.57 \mu \mathrm{gL}^{-1}$ (groundwater). The respective $\mathrm{CV}$ and SD were 48.68 and 10.06, 24.68 and 4.08 for pond and groundwater (Table 1). WHO (1971) and USEPA (1975) recommended the Mn concentration for drinking is 0.1 to $1.0 \mathrm{mgL}^{-1}$ and $0.05 \mathrm{mgL}^{-1}$. Based on this 1 pond water (No. 9) was not suitable but all others were suitable for drinking (Table 2). Except 1 pond water (No. 9) all other samples were suitable for livestock consumption (Table 5), this is because it contained $>0.5 \mathrm{mgL}^{-1}$ of $\mathrm{Mn}$, the samples were also suitable for irrigation (Ayers and Westcot, 1985). Meade (1989) reported that the Mn concentration for aquaculture is $<0.01 \mathrm{mgL}^{-1}$ and samples were not suitable (Table 4).

\subsection{Zinc (Zn)}

Zinc values of pond and groundwater ranged from 6.02 to $44.16 \mu \mathrm{gL}^{-1}$ and 6.02 to $44.10 \mu \mathrm{gL}^{-1}$, respectively. The mean value of $22.99 \mu \mathrm{gL}^{-1}$ (pond) and $19.41 \mu \mathrm{gL}^{-1}$ (groundwater). The respective SD and CV were 11.12 and $10.05,48.41$ and 51.82 (Table 1). The $\mathrm{Zn}$ concentration limit for aquaculture is $<0.005 \mathrm{mgL}^{-1}$, according to Meade (1989) the samples were not suitable for aquaculture (Table 4). The recommended limit of iron for drinking is 5 to $15 \mathrm{mgL}^{-1}$ and $5 \mathrm{mgL}^{-1}$ (WHO, 1971 and USEPA, 1975). Based on this recommendation the samples were suitable for drinking (Table 2). The sample of the study area does not exceed the recommended limit for irrigation and livestock consumption (Table 3, 4) according to Ayers and Westcot (1985).

\subsection{Boron $(B)$}

Boron concentration of pond and ground water samples varied from ND to $0.18 \mathrm{mgL}^{-1}$ and ND to $0.16 \mathrm{mgL}^{-1}$, with the mean value of 0.08 and $0.07 \mathrm{mg} \mathrm{L}^{-1}$, respectively. The respective SD and CV were 0.05 and $0.06,75.16$ and 84.32 (Table 1). The recommended maximum concentrations of $\mathrm{B}$ are less than $0.75 \mathrm{mgL}^{-1}$ (Ayers and Wcstoot, 1985) for irrigating of agricultural crops. B content above recommended limit is harmful for the soils and crops. Boron (B) is essential for all plants and required in relatively micro amounts. Surface water rarely 
contains enough B to be toxic but wells water or springs occasionally contain toxic amounts especially near geothermal areas.

\subsection{4. $\mathrm{CO}_{3}$ and $\mathrm{HCO}_{3}$}

None of the samples were responded to $\mathrm{CO}_{3}$ test. $\mathrm{HCO}_{3}$ values fluctuated from 73.20 to 219.60 and 97.60 to $463.60 \mathrm{mgL}^{-1}$, having the mean value of 141.96 and $263.96 \mathrm{mgL}^{-1}$, respectively for pond and groundwater. The respective $\mathrm{SD}$ and $\mathrm{CV}$ were 50.38 and $132.55,35.49$ and 50.21, respectively. $\mathrm{HCO}_{3}$ concentrations were found almost at normal level. Bicarbonates are derived mainly from the soil zone $\mathrm{CO}_{2}$ and dissolution of carbonates and reaction of silicates with carbonic acid. The soil zone in the subsurface environment contains elevated $\mathrm{CO}_{2}$ pressure (produced as result of decay of organic matter and root respiration), which in turn combines with rainwater to form bicarbonate. Bicarbonate may also be derived from the dissolution of carbonates and/or silicate minerals by the carbonic acid (Singh et al., 2009).

\subsection{Arsenic (As)}

All the water sources were free from As contamination (Table 1). The recommended and tolerance limit of arsenic for drinking water are 0.01 and $0.05 \mathrm{mg} \mathrm{L}^{-1}$ (USEPA, 1975). As per reports of Ayers and Westcot (1985) and Meade (1989) the waters under test were found suitable for irrigation, livestock consumption and aquaculture.

\subsection{Phosphorus (P)}

Phosphorus concentration fluctuated from 0.15 to $0.72 \mathrm{mgL}^{-1}$ (pond) and ND to $0.84 \mathrm{mgL}^{-1}$ (groundwater). The respective mean, SD and CV of pond and groundwater were 0.42 and $0.40,0.18$ and $0.22,43.60$ and 55.85, respectively. The maximum permissible limit of $\mathrm{P}$ in irrigation water is $2.00 \mathrm{mg} \mathrm{L}^{-1}$ (Ayers and Westcot, 1985) and the samples were suitable for irrigation. The present investigation showed that the $\mathrm{P}$ concentration in groundwater sources of Barisal upazila might not be harmful for multipurpose use.

\subsection{Sodium Adsorption Ratio (SAR)}

The SAR values ranged from 1.41 to 6.53 (pond) and 2.51 to 5.23 (groundwater). With the mean, SD and CV of pond and groundwater were 3.83 and 3.73, 1.59 and 0.83, 41.56 and 22.42 (Table 3). Based on Todd (1980) SAR categorized all the samples "excellent" class for irrigation except 2 groundwater samples (sample no. 5 and 6). SAR and EC combinedly classified the pond and tube-well water as "low salinity" and "low alkalinity" (C1S1), "medium salinity" 'low alkalinity" (C2S1) group respectively for irrigation Richards (1968). A high Na concentration changes soil properties and reduces soil permeability, which leads to development of an alkaline soil (Singh et al., 2010).

\subsection{Soluble Sodium Percentage (SSP)}

SSP values of pond and tube-well water ranged from 17.69 to 41.46 and 16.31 to 32.10 and the mean, SD and CV of 26.39 and 23.32, 7.09 and 4.83, 26.87 and 20.73, respectively (Table 3). Among 22 samples of both pond and tube-well SSP rated 6 samples as "excellent" 15 were "good" and 01 as "permissible" for irrigation according to the classification of Wilcox (1955).

\subsection{Potassium adsorption ratio (PAR)}

The PAR value fluctuated from 0.87 to 4.43 (pond) and 0.69 to 1.47 (tube-well) with the average of 2.08 and 0.98 , the SD and CV were 1.07 and $0.24,51.51$ and 25.04, respectively (Table 3). Based on PAR values the waters would not be harmful for agricultural corps.

\subsection{Residual Sodium Carbonate (RSC)}

RSC of the pond and tube-well water fluctuated from -2.47 to 0.84 and -2.27 to $4.80 \mathrm{meL}^{-1}$; having mean, SD and CV of 0.40 and 1.34, 0.96 and 2.53, 242.45 and 188.80, respectively (Table 3). On the basis of RSC, Eaton (1950) classified irrigation water into suitable (RSC $<1.25 \mathrm{meL}^{-1}$ ), marginal (RSC 1.25-2.50 meL $\mathrm{m}^{-1}$ ) and unsuitable (RSC >2.50 meL ${ }^{-1}$ ). Based on This classification among 22 samples (pond + tube-well) 15 samples were "suitable", 03 were "marginal" and 04 were "unsuitable" for irrigation (Table 3). The quantity of bicarbonate and carbonate in excess of alkaline earths $\left(\mathrm{Ca}^{2+}+\mathrm{Mg}^{2+}\right)$ also influence the suitability of water for irrigation purposes. When the sum of carbonates and bicarbonates is in excess of calcium and magnesium, precipitation $\mathrm{Ca}$ and $\mathrm{Mg}$ may occur (Raghunath, 1987). The effects of carbonate and bicarbonate, and suitability of water for irrigation can be assessed by computing residual sodium carbonate (RSC). 
3.21. Hardness $\left(\mathbf{H}_{\mathrm{T}}\right)$

Hardness of samples fluctuated from 88.09 to $195.70 \mathrm{mgL}^{-1}$ (pond) and 104.06 to $203.73 \mathrm{mgL}^{-1}$ (tube-well). The mean, SD and CV of pond and groundwaters were 136.59 and 148.34, 35.60 and 29.41, 26.06 and 19.82, respectively (Table 3). With respect to $\mathrm{H}_{\mathrm{T}}$, out of 22 samples (pond + tube-well) 13 were "moderately hard" and 09 were "hard" limit for irrigation and the samples were suitable for livestock consumption as per reports of Ayers and Westcot (1985). Hardness of water is due to the presence of sulphates and chlorides of $\mathrm{Ca}$ and $\mathrm{Mg}$. According to Meade (1989) all the samples were suitable for aquaculture.

Table 1. Sampling information and chemical constituents of pond and groundwater.

\begin{tabular}{|c|c|c|c|c|c|c|c|c|c|c|c|c|c|c|c|c|c|c|c|}
\hline \multirow{2}{*}{$\begin{array}{l}\text { SL. } \\
\text { NO. }\end{array}$} & \multirow[b]{2}{*}{ Village name } & \multicolumn{2}{|c|}{$\mathbf{p H}$} & \multicolumn{2}{|c|}{$\mathrm{EC}\left(\mu \mathrm{Scm}^{-1}\right)$} & \multicolumn{2}{|c|}{ TDS (ppm) } & \multicolumn{2}{|c|}{$\mathrm{Ca}$ (ppm) } & \multicolumn{2}{|c|}{ Mg (ppm) } & \multicolumn{2}{|c|}{$\mathrm{Na}(\mathrm{ppm})$} & \multicolumn{2}{|c|}{ K (ppm) } & \multicolumn{2}{|c|}{ As (ppm) } & \multicolumn{2}{|c|}{$\mathrm{CO}_{3}(\mathrm{ppm})$} \\
\hline & & Pond & $\begin{array}{l}\text { Tube } \\
\text {-well }\end{array}$ & Pond & $\begin{array}{l}\text { Tube- } \\
\text { well }\end{array}$ & Pond & $\begin{array}{l}\begin{array}{l}\text { Tube- } \\
\text { well }\end{array} \\
\end{array}$ & Pond & $\begin{array}{l}\text { Tube } \\
\text {-well }\end{array}$ & Pond & $\begin{array}{l}\text { Tube } \\
\text {-well }\end{array}$ & Pond & \begin{tabular}{|c|} 
Tube \\
-well
\end{tabular} & Pond & $\begin{array}{l}\text { Tube } \\
\text {-well }\end{array}$ & Pond & $\begin{array}{l}\text { Tube } \\
\text {-well }\end{array}$ & Pond & $\begin{array}{l}\text { Tube } \\
\text {-well }\end{array}$ \\
\hline 1 & Char Kowa & 6.75 & 6.10 & 138.50 & 574.00 & 125.70 & 434.00 & 32.06 & 24.04 & 14.58 & 17.50 & 11.41 & 18.70 & 4.23 & 4.23 & ND & ND & ND & ND \\
\hline 2 & Karnakathi & 7.21 & 6.70 & 205.60 & 588.00 & 198.70 & 366.00 & 24.04 & 19.23 & 16.53 & 14.58 & 15.86 & 21.54 & 8.83 & 3.40 & ND & ND & ND & ND \\
\hline 3 & Kalijira & 6.44 & 6.80 & 149.00 & 509.00 & 135.90 & 350.00 & 30.46 & 16.03 & 26.26 & 29.17 & 31.27 & 17.89 & 18.03 & 5.49 & ND & ND & ND & ND \\
\hline 4 & Karapur & 6.94 & 6.43 & 120.00 & 502.00 & 121.90 & 475.00 & 32.06 & 25.65 & 4.863 & 18.47 & 12.22 & 16.27 & 8.41 & 4.23 & ND & ND & ND & ND \\
\hline 5 & Kashipur & 6.23 & 6.44 & 190.00 & 560.00 & 223.50 & 377.00 & 24.04 & 28.85 & 33.06 & 32.09 & 34.92 & 17.08 & 9.25 & 3.81 & ND & ND & ND & ND \\
\hline 6 & Shayestabad & 6.43 & 6.89 & 195.00 & 820.00 & 103.60 & 321.00 & 19.23 & 25.65 & 24.31 & 21.39 & 21.94 & 12.22 & 13.02 & 7.16 & ND & ND & ND & ND \\
\hline 7 & Chor Monai & 6.69 & 6.20 & 84.60 & 802.00 & 176.90 & 434.00 & 28.85 & 27.25 & 3.890 & 16.53 & 5.735 & 21.54 & 8.00 & 5.91 & ND & ND & ND & ND \\
\hline 8 & Chandpur & 6.32 & 6.91 & 152.20 & 567.00 & 141.00 & 391.00 & 19.23 & 30.46 & 17.50 & 6.80 & 12.22 & 15.46 & 6.32 & 3.40 & ND & ND & ND & ND \\
\hline 9 & Tungibaria & 6.31 & 7.08 & 90.00 & 496.00 & 168.00 & 388.00 & 16.03 & 19.23 & 12.64 & 31.12 & 20.32 & 12.62 & 16.78 & 5.49 & ND & ND & ND & ND \\
\hline 10 & Chandramohan & 6.25 & 6.60 & 100.10 & 480.00 & 177.20 & 367.00 & 14.42 & 27.25 & 26.26 & 25.28 & 13.43 & 19.51 & 4.65 & 5.07 & ND & ND & ND & ND \\
\hline 11 & Jagua & 7.10 & 6.55 & 239.00 & 468.00 & 196.40 & 390.00 & 9.619 & 24.04 & 34.04 & 23.34 & 17.49 & 21.13 & 5.91 & 3.40 & ND & ND & ND & ND \\
\hline Range & & $\begin{array}{l}6.23- \\
7.21\end{array}$ & $\begin{array}{c}6.10- \\
7.08\end{array}$ & $\begin{array}{l}84.60- \\
239.00\end{array}$ & $\begin{array}{c}468.00- \\
820.00\end{array}$ & $\begin{array}{l}103.6- \\
223.50\end{array}$ & $\begin{array}{c}321.00- \\
475.00\end{array}$ & $\begin{array}{l}9.61- \\
32.06\end{array}$ & $\begin{array}{l}16.03- \\
30.46\end{array}$ & $\begin{array}{l}3.890- \\
34.04\end{array}$ & $\begin{array}{l}6.80- \\
32.09\end{array}$ & $\begin{array}{l}5.73- \\
34.92\end{array}$ & $\begin{array}{l}12.22- \\
21.54\end{array}$ & $\begin{array}{l}4.23- \\
18.03\end{array}$ & $\begin{array}{c}3.40- \\
7.16\end{array}$ & - & - & - & - \\
\hline Mean & & 6.60 & 6.60 & 151.27 & 578.72 & 160.8 & 390.27 & 22.73 & 24.33 & 19.45 & 21.48 & 17.89 & 17.63 & 9.4 & 4.69 & - & - & - & - \\
\hline SD & & 0.35 & 0.30 & 51.01 & 121.76 & 37.74 & 43.28 & 7.64 & 4.46 & 10.25 & 7.71 & 8.77 & 3.29 & 4.65 & 1.23 & - & - & - & - \\
\hline $\mathrm{CV}(\%)$ & & 5.34 & 4.61 & 33.72 & 21.03 & 23.47 & 11.09 & 33.65 & 18.36 & 52.73 & 35.90 & 49.03 & 18.71 & 49.47 & 26.27 & - & - & - & - \\
\hline
\end{tabular}


Table 1. Continued...

\begin{tabular}{|c|c|c|c|c|c|c|c|c|c|c|c|c|c|c|c|c|c|}
\hline \multirow[b]{2}{*}{ SL. NO. } & \multirow[b]{2}{*}{ Upazila } & \multicolumn{2}{|c|}{ Cl (ppm) } & \multicolumn{2}{|c|}{$\mathrm{HCO}_{3}(\mathrm{ppm})$} & \multicolumn{2}{|c|}{$\mathbf{P}(\mathbf{p p m})$} & \multicolumn{2}{|c|}{ B (ppm) } & \multicolumn{2}{|c|}{ Fe (ppb) } & \multicolumn{2}{|c|}{ Mn (ppb) } & \multicolumn{2}{|c|}{$\mathbf{Z n}(\mathbf{p p b})$} & \multicolumn{2}{|c|}{$\mathrm{Cu}(\mathbf{p p m})$} \\
\hline & & Pond & $\begin{array}{l}\text { Tube- } \\
\text { well }\end{array}$ & Pond & $\begin{array}{l}\text { Tube- } \\
\text { well }\end{array}$ & Pond & $\begin{array}{l}\text { Tube- } \\
\text { well }\end{array}$ & Pond & $\begin{array}{l}\text { Tube- } \\
\text { well }\end{array}$ & Pond & $\begin{array}{l}\text { Tube- } \\
\text { well }\end{array}$ & Pond & \begin{tabular}{|l}
$\begin{array}{l}\text { Tube- } \\
\text { well }\end{array}$ \\
\end{tabular} & Pond & $\begin{array}{l}\text { Tube- } \\
\text { well }\end{array}$ & Pond & $\begin{array}{l}\text { Tube- } \\
\text { well }\end{array}$ \\
\hline 1 & Char Kowa & 29.99 & 139.95 & 158.60 & 390.40 & 0.49 & 0.49 & 0.09 & 0.05 & 94.6 & 75.08 & 40.57 & 41.42 & 25.09 & 12.05 & ND & 0.05 \\
\hline 2 & Karnakathi & 27.99 & 105.96 & 195.20 & 341.60 & 0.31 & 0.29 & 0.11 & 0.16 & 101.25 & 154.22 & 56.29 & 45.07 & 17.08 & 12.05 & ND & ND \\
\hline 3 & Kalijira & 63.98 & 115.96 & 73.20 & 146.40 & 0.72 & 0.37 & 0.18 & 0.05 & 77.34 & 87.5 & 44.78 & 40.47 & 17.08 & 23.06 & ND & ND \\
\hline 4 & Karapur & 15.99 & 109.96 & 170.80 & 463.60 & 0.19 & 0.35 & 0.06 & ND & 112.12 & 111.11 & 55.29 & 33.43 & 36.24 & 12.05 & ND & 0.02 \\
\hline 5 & Kashipur & 31.99 & 105.96 & 219.60 & 109.80 & 0.35 & 0.84 & 0.03 & 0.09 & 56.63 & 87.5 & 37.87 & 45.04 & 18.08 & 24.1 & ND & ND \\
\hline 6 & Shayestabad & 25.99 & 101.96 & 122.00 & 109.80 & 0.55 & 0.31 & ND & 0.14 & 103.71 & 87.5 & 33.24 & 40.47 & 6.02 & 44.1 & ND & $\mathrm{ND}$ \\
\hline 7 & Chor Monai & 35.98 & 111.96 & 158.60 & 390.40 & 0.65 & 0.23 & 0.08 & 0.12 & 88.88 & 88.34 & 46.08 & 35.85 & 44.16 & 20.02 & ND & 0.02 \\
\hline 8 & Chandpur & 17.99 & 109.96 & 85.40 & 219.60 & 0.39 & ND & 0.11 & ND & 144.1 & 81.1 & 51.6 & 40.46 & 25.09 & 6.02 & ND & ND \\
\hline 9 & Tungibaria & 11.99 & 115.96 & 73.20 & 97.60 & 0.15 & 0.68 & 0.14 & 0.13 & 111.11 & 88.87 & 120.81 & 46.78 & 18.07 & 24.06 & ND & ND \\
\hline 10 & Chandramohan & 47.98 & 171.94 & 122.00 & 292.80 & 0.51 & 0.35 & ND & 0.03 & 124.26 & 97.7 & 40.47 & 36.86 & 33.04 & 18.07 & ND & ND \\
\hline 11 & Jagua & 11.99 & 95.97 & 183.00 & 341.60 & 0.29 & 0.47 & 0.03 & ND & 102.8 & 100.45 & 30.86 & 40.47 & 13.04 & 18.07 & ND & 0.03 \\
\hline Range & & $\begin{array}{l}11.99- \\
63.98\end{array}$ & $\begin{array}{l}95.97- \\
171.94\end{array}$ & $\begin{array}{l}73.20- \\
219.60\end{array}$ & $\begin{array}{l}97.60- \\
463.60\end{array}$ & $\begin{array}{l}0.15- \\
0.72\end{array}$ & $\begin{array}{l}\text { ND - } \\
0.84\end{array}$ & $\begin{array}{l}\text { ND - } \\
0.18\end{array}$ & $\begin{array}{l}\text { ND - } \\
0.16\end{array}$ & $\begin{array}{l}56.63- \\
144.10\end{array}$ & $\begin{array}{l}75.08- \\
154.22\end{array}$ & $\begin{array}{l}30.86- \\
120.81\end{array}$ & $\begin{array}{l}33.43- \\
46.78\end{array}$ & $\begin{array}{l}6.02- \\
44.16\end{array}$ & $\begin{array}{l}6.02- \\
44.10\end{array}$ & - & $\begin{array}{l}\text { ND - } \\
0.048\end{array}$ \\
\hline Average & & 29.26 & 116.87 & 141.96 & 263.96 & 0.42 & 0.40 & 0.08 & 0.07 & 110.52 & 96.30 & 50.71 & 40.57 & 22.99 & 19.41 & - & 0.01 \\
\hline SD & & 15.87 & 21.41 & 50.38 & 132.55 & 0.18 & 0.22 & 0.060 & 0.06 & 23.12 & 21.50 & 24.68 & 4.08 & 11.12 & 10.05 & - & 0.01 \\
\hline $\mathrm{CV}(\%)$ & & 54.25 & 18.31 & 35.49 & 50.21 & 43.60 & 55.85 & 75.16 & 84.32 & 20.92 & 22.33 & 48.68 & 10.06 & 48.41 & 51.82 & - & 164.94 \\
\hline
\end{tabular}


Table 2. Water Classification for drinking (WHO, 1971 and U.S. Environmental Protection Agency, 1975).

\begin{tabular}{|c|c|c|c|c|c|c|c|c|c|c|c|c|c|c|c|c|c|c|c|c|c|c|}
\hline \multirow{2}{*}{$\begin{array}{l}\text { SL. } \\
\text { NO. }\end{array}$} & \multicolumn{2}{|c|}{ pH } & \multicolumn{2}{|c|}{ TDS (ppm) } & \multicolumn{2}{|c|}{ Ca (ppm) } & \multicolumn{2}{|c|}{ Mg (ppm) } & \multicolumn{2}{|c|}{$\mathbf{H}_{\mathrm{T}}(\mathbf{p p m})$} & \multicolumn{2}{|c|}{$\mathrm{Fe}(\mathbf{p p b})$} & \multicolumn{2}{|c|}{ Mn (ppb) } & \multicolumn{2}{|c|}{ Zn (ppb) } & \multicolumn{2}{|c|}{$\mathrm{Cl}$ (ppm) } & \multicolumn{2}{|c|}{$\mathrm{Cu}$ (ppm) } & \multicolumn{2}{|c|}{ As (ppm) } \\
\hline & Pond & $\begin{array}{l}\text { Tube- } \\
\text { well }\end{array}$ & Pond & \begin{tabular}{|l|} 
Tube- \\
well
\end{tabular} & Pond & \begin{tabular}{|l|} 
Tube- \\
well
\end{tabular} & Pond & \begin{tabular}{|l|} 
Tube- \\
well
\end{tabular} & Pond & \begin{tabular}{|l|} 
Tube- \\
well
\end{tabular} & Pond & \begin{tabular}{|l|} 
Tube- \\
well
\end{tabular} & Pond & \begin{tabular}{|l|} 
Tube- \\
well
\end{tabular} & Pond & \begin{tabular}{|l|} 
Tube- \\
well
\end{tabular} & Pond & $\begin{array}{l}\text { Tube- } \\
\text { well }\end{array}$ & Pond & \begin{tabular}{|l|} 
Tube- \\
well
\end{tabular} & Pond & $\begin{array}{l}\text { Tube- } \\
\text { well }\end{array}$ \\
\hline 1 & 6.75 & 6.10 & 125.70 & 434.00 & 32.06 & 24.04 & 14.58 & 17.50 & 139.97 & 131.8 & 94.6 & 75.08 & 40.57 & 41.42 & 25.09 & 12.05 & 29.99 & 139.95 & ND & 0.05 & ND & ND \\
\hline 2 & 7.21 & 6.70 & 198.70 & 366.00 & 24.04 & 19.23 & 16.53 & 14.58 & 27.91 & 107.9 & 101.25 & 154.22 & 56.29 & 45.07 & 17.08 & 12.05 & 27.99 & 105.96 & ND & ND & ND & ND \\
\hline 3 & 6.44 & 6.80 & 135.90 & 350.00 & 30.46 & 16.03 & 26.26 & 29.17 & 83.81 & 159.7 & 77.34 & 87.5 & 44.78 & 40.47 & 17.08 & 23.06 & 63.98 & 115.96 & ND & ND & ND & ND \\
\hline 4 & 6.94 & 6.43 & 121.90 & 475.00 & 32.06 & 25.65 & 4.863 & 18.47 & 100.09 & 139.8 & 112.12 & 111.11 & 55.29 & 33.43 & 36.24 & 12.05 & 15.99 & 109.96 & ND & 0.02 & ND & ND \\
\hline 5 & 6.23 & 6.44 & 223.50 & 377.00 & 24.04 & 28.85 & 33.06 & 32.09 & 195.70 & 203.7 & 56.63 & 87.5 & 37.87 & 45.04 & 18.08 & 24.1 & 31.99 & 105.96 & ND & ND & ND & ND \\
\hline 6 & 6.43 & 6.89 & 103.60 & 321.00 & 19.23 & 25.65 & 24.31 & 21.39 & 147.78 & 151.8 & 103.71 & 87.5 & 33.24 & 40.47 & 6.02 & 44.1 & 25.99 & 101.96 & ND & ND & ND & ND \\
\hline 7 & 6.69 & 6.20 & 176.90 & 434.00 & 28.85 & 27.25 & 3.890 & 16.53 & 88.09 & 135.9 & 88.88 & 88.34 & 46.08 & 35.85 & 44.16 & 20.02 & 35.98 & 111.96 & ND & 0.02 & ND & ND \\
\hline 8 & 6.32 & 6.91 & & & & & & & & & & & & & & & & & & & ND & \\
\hline 9 & 6.31 & 7.08 & 168.00 & 388.00 & 16.03 & 19.23 & 12.64 & 31.12 & 91.91 & 175.7 & 111.11 & 88.87 & 120.8 & 46.78 & 18.07 & 24.06 & 11.99 & 115.96 & ND & ND & ND & ND \\
\hline 10 & 6.25 & 6.60 & 177.20 & 367.00 & 14.42 & 27.25 & 26.26 & 25.28 & 143.73 & 171.8 & 124.26 & 97.7 & 40.47 & 36.86 & 33.04 & 18.07 & 47.98 & 171.94 & ND & ND & ND & ND \\
\hline 11 & 7.10 & 6.55 & 196.40 & 390.00 & 9.619 & 24.04 & 34.04 & 23.34 & 163.61 & 155.8 & 102.8 & 100.45 & 30.86 & 40.47 & 13.04 & 18.07 & 11.99 & 95.97 & ND & 0.03 & ND & ND \\
\hline Range & $\begin{array}{l}6.23- \\
7.21\end{array}$ & $\begin{array}{l}6.10- \\
7.08\end{array}$ & $\begin{array}{l}103.6- \\
223.50\end{array}$ & $\begin{array}{l}321.00- \\
475.00\end{array}$ & $\begin{array}{l}9.61- \\
32.06\end{array}$ & $\begin{array}{l}16.03- \\
30.46\end{array}$ & $\begin{array}{l}3.890- \\
34.04\end{array}$ & $\begin{array}{l}6.80- \\
32.09\end{array}$ & $\begin{array}{l}88.09- \\
195.70\end{array}$ & $\begin{array}{l}104.0- \\
203.7\end{array}$ & $\begin{array}{l}56.63- \\
144.10\end{array}$ & $\begin{array}{l}75.08- \\
154.22\end{array}$ & $\begin{array}{l}30.86- \\
120.8\end{array}$ & $\begin{array}{l}33.43- \\
46.78\end{array}$ & $\begin{array}{l}6.02- \\
44.16\end{array}$ & $\begin{array}{l}6.02- \\
44.10\end{array}$ & $\begin{array}{l}11.99- \\
63.98\end{array}$ & $\begin{array}{l}95.97- \\
171.94\end{array}$ & - & $\begin{array}{l}\text { ND - } \\
0.048\end{array}$ & - & - \\
\hline Mean & 6.60 & 6.60 & 160.8 & 390.27 & 22.73 & 24.33 & 19.45 & 21.48 & 136.59 & 148.3 & 110.52 & 96.30 & 50.71 & 40.57 & 22.99 & 19.41 & 29.26 & 116.87 & - & 0.01 & - & - \\
\hline SD & 0.35 & 0.30 & 37.74 & 43.28 & 7.64 & 4.46 & 10.25 & 7.71 & 35.60 & 29.41 & 23.12 & 21.50 & 24.68 & 4.08 & 11.12 & 10.05 & 15.87 & 21.41 & - & 0.01 & - & - \\
\hline $\mathrm{CV}(\%)$ & 5.34 & 4.61 & 23.47 & 11.09 & 33.65 & 18.36 & 52.73 & 35.90 & 26.06 & 19.82 & 20.92 & 22.33 & 48.68 & 10.06 & 48.41 & 51.82 & 54.25 & 18.31 & - & 164.94 & - & - \\
\hline
\end{tabular}

Key : ND= Not detectible $\left(<0.0001 \mathrm{mgL}^{-1}\right)$ 
Table 3. Classification of water for irrigation based on Ayers and Westcot (1985); Freeze and Cherry (1979); Todd (1980); Sawyer and McCarty ( 1967); Eaton ( 1950) and Richards (1968).

\begin{tabular}{|c|c|c|c|c|c|c|c|c|c|c|c|c|c|c|c|c|c|c|c|c|c|c|c|c|}
\hline \multirow{2}{*}{$\begin{array}{l}\text { SL. } \\
\text { NO. }\end{array}$} & \multicolumn{2}{|c|}{$\mathrm{EC}\left(\mu \mathrm{Scm}^{-1}\right)$} & \multicolumn{2}{|c|}{ TDS (ppm) } & \multicolumn{2}{|c|}{ SAR } & \multicolumn{2}{|c|}{ PAR } & \multicolumn{2}{|c|}{ SSP $(\%)$} & \multicolumn{2}{|c|}{$\operatorname{RSC}\left(\mathrm{meL}^{-1}\right)$} & \multicolumn{2}{|c|}{$\mathrm{Fe}(\mathrm{ppb})$} & \multicolumn{2}{|c|}{ Mn (ppb) } & \multicolumn{2}{|c|}{ Zn (ppb) } & \multicolumn{2}{|c|}{$\mathbf{H}_{\mathrm{T}}(\mathbf{p p m})$} & \multicolumn{2}{|c|}{ B (ppm) } & \multicolumn{2}{|c|}{$\begin{array}{c}\text { Alkalinity } \\
\text { and salinity } \\
\text { hazard }\end{array}$} \\
\hline & Pond & & Pond & & ond & & ond & & Pond & & Pond & & Pond & & Pond & & Pond & & Pond & & Pond & & Pond & $\begin{array}{c}\text { Tube } \\
\text {-well }\end{array}$ \\
\hline 1 & 8.50 & 574.00 & 125.70 & 434.00 & 2.36 & 4.10 & 0.87 & 0.92 & 17.69 & 25.82 & -0.19 & 3.76 & 94.6 & 75.08 & 40.57 & 41.42 & 25.09 & 12.05 & 139.97 & 131.8 & 0.09 & 0.05 & C1S1 & $\mathrm{C} 2 \mathrm{~S} 1$ \\
\hline 2 & 05.60 & 588.00 & 198.70 & 366.00 & 3.52 & 5.23 & 106 & 0.82 & 26.24 & 32.10 & 064 & 3.44 & 101.25 & 154.22 & 56.29 & 45.07 & 17.08 & 12.05 & 127.91 & 107.9 & 0.11 & 0.16 & $\mathrm{C} 1 \mathrm{~S} 1$ & $\mathrm{C} 2 \mathrm{~S} 1$ \\
\hline 3 & 149.00 & 509.00 & 135.90 & 350.00 & 5.87 & 3.76 & 3.38 & 1.15 & 32.97 & 22.24 & 47 & -0.79 & 77.34 & 87.5 & 44.78 & 40.47 & 17.08 & 23.06 & 183.81 & 159.7 & 0.18 & 0.05 & $1 \mathrm{~S} 1$ & $\mathrm{C} 2 \mathrm{~S} 1$ \\
\hline 4 & 20.00 & 02.00 & 121.90 & 475.00 & 2.84 & 3.46 & 1.95 & 0.90 & 27.05 & 22.51 & 0.80 & 4.80 & 112.12 & 111.11 & 55.29 & 33.43 & 36.24 & 12.05 & 100.09 & 139.8 & 0.06 & ND & $\mathrm{C} 1 \mathrm{~S} 1$ & $\mathrm{C} 2 \mathrm{~S} 1$ \\
\hline & 190.00 & 560.00 & 223.50 & 377.00 & 6.53 & 5.0 & 173 & 0.69 & 30.85 & 17.04 & 0.01 & -2.27 & 56.63 & 87.5 & 37.87 & 45.04 & 18.08 & 24.10 & 195.70 & 203.7 & 0.05 & 0.09 & C1S1 & $\mathrm{C} 2 \mathrm{~S} 1$ \\
\hline 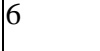 & 195.00 & 20.00 & 103.60 & 321.00 & 4.70 & 2.51 & 2.79 & 1.47 & 30.18 & 18.94 & -095 & -1.23 & 103.71 & 87.5 & 33.24 & 40.47 & 6.02 & 44.10 & 147.78 & 151.8 & ND & 0.14 & $\mathrm{C} 1 \mathrm{~S} 1$ & $\mathrm{C} 3 \mathrm{~S} 1$ \\
\hline 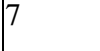 & 84.60 & 802.00 & 176.90 & 434.00 & 1.41 & 4.60 & & 1.26 & 20.34 & 28.50 & .04 & 3.68 & 88.88 & 88.34 & 46.08 & 35.85 & 44.16 & 20.02 & 88.09 & 135.9 & 0.08 & 0.12 & C1S1 & C3S1 \\
\hline 8 & 152.20 & 567.00 & 141.00 & 391.00 & 2.85 & 358 & 147 & 0.78 & 22.31 & 26.68 & 000 & 1.52 & 144.1 & 81.1 & 51.6 & 40.46 & 25.09 & 6.02 & 119.87 & 104.0 & 011 & ND & $\mathrm{C} 1 \mathrm{~S} 1$ & $\mathrm{C} 2 \mathrm{~S} 1$ \\
\hline 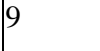 & 90.00 & 496.00 & 168.00 & 388.00 & 5.36 & 2.51 & 4.43 & 1.09 & 41.46 & 16.31 & -0.63 & -1.91 & 111.11 & 88.87 & 120.8 & 46.78 & 18.07 & 24.06 & 91.91 & 175.7 & 0.14 & 0.13 & C1S1 & $\mathrm{C} 2 \mathrm{~S} 1$ \\
\hline 10 & 100.10 & 480.00 & 177.20 & 367.00 & 2.97 & 3.00 & 102 & 0.98 & 19.56 & 22.08 & -0.87 & 1.36 & 124.26 & 97.7 & 40.47 & 36.86 & 33.02 & 18.07 & & 171.8 & ND & 0.03 & $\mathrm{C} 1 \mathrm{~S} 1$ & $\mathrm{C} 2 \mathrm{~S} 1$ \\
\hline 11 & 39.00 & 468.00 & 196.40 & 390.00 & & & & & & 24.34 & & 2.48 & & & & & & & & & & & & $\mathrm{C} 2 \mathrm{~S} 1$ \\
\hline Range & $\begin{array}{l}84.60- \\
239.00\end{array}$ & $\begin{array}{l}468.00 \\
- \\
820.00\end{array}$ & $\begin{array}{l}103.6- \\
223.50\end{array}$ & $\begin{array}{l}321.00 \\
- \\
475.00\end{array}$ & & $\begin{array}{l}2.51- \\
5.23\end{array}$ & $\begin{array}{l}0.87- \\
4.43\end{array}$ & $\begin{array}{l}0.69- \\
1.47\end{array}$ & $\begin{array}{l}17.69- \\
41.46\end{array}$ & $\begin{array}{l}16.31- \\
32.10\end{array}$ & $\begin{array}{l}-2.47- \\
0.84\end{array}$ & $\begin{array}{l}2.27- \\
4.80\end{array}$ & $\begin{array}{l}56.63- \\
144.10\end{array}$ & $\begin{array}{l}75.08- \\
154.22\end{array}$ & $\begin{array}{l}30.8- \\
120.8\end{array}$ & $\begin{array}{l}33.4- \\
46.78\end{array}$ & $\begin{array}{l}6.02- \\
44.16\end{array}$ & $\begin{array}{l}6.02- \\
44.10\end{array}$ & & $\begin{array}{l}104.0- \\
203.7\end{array}$ & $\begin{array}{l}\text { ND - } \\
0.18\end{array}$ & $\begin{array}{l}\text { ND - } \\
0.16\end{array}$ & - & - \\
\hline Mean & & & & & & & & & & & & & & & & & & & & & & & & - \\
\hline & & & & & & & & & & & & 2.53 & & & & & & 10.05 & & & & 0.06 & - & - \\
\hline$(\%)$ & 33.72 & 21.03 & 23.47 & 11.09 & 41.56 & 22.42 & 51.51 & 25.04 & 26.87 & 20.73 & 242.45 & 188.8 & 20.92 & 22.33 & 48.68 & 10.06 & 48.41 & 51.82 & 26.06 & 19.82 & 75.16 & 84.32 & - & - \\
\hline
\end{tabular}

Keys: $\mathrm{ND}=$ Not detectible $\left(<0.0001 \mathrm{mgL}^{-1}\right), \mathrm{C} 1=$ Low salinity, $\mathrm{C} 2=$ Medium salinity, C3=High Salinity, S1=Low alkalinity, 
Table 4. Classification of pond water for aquaculture (Meade, 1989).

\begin{tabular}{|c|c|c|c|c|c|c|c|c|c|c|c|c|c|}
\hline SL. NO. & $\mathbf{p H}$ & TDS (ppm) & $\mathrm{Ca}(\mathbf{p p m})$ & Mg (ppm) & $\mathrm{Na}(\mathrm{ppm})$ & $\mathbf{K}(\mathbf{p p m})$ & $\mathbf{H}_{\mathrm{T}}(\mathbf{p p m})$ & $\mathrm{Fe}(\mathrm{ppb})$ & Mn (ppb) & $\mathrm{Zn}(\mathbf{p p b})$ & $\mathrm{Cl}$ (ppm) & $\mathrm{Cu}(\mathbf{p p m})$ & As (ppm) \\
\hline 1 & 6.75 & 125.70 & 32.06 & 14.58 & 11.41 & 4.23 & 139.97 & 94.60 & 40.57 & 25.09 & 29.99 & ND & ND \\
\hline 2 & 7.21 & 198.70 & 24.04 & 16.53 & 15.86 & 8.83 & 127.91 & 101.25 & 56.29 & 17.08 & 27.99 & ND & ND \\
\hline 3 & 6.44 & 135.90 & 30.46 & 26.26 & 31.27 & 18.03 & 183.81 & 77.34 & 44.78 & 17.08 & 63.98 & ND & ND \\
\hline 4 & 6.94 & 121.90 & 32.06 & 4.863 & 12.22 & 8.41 & 100.09 & 112.12 & 55.29 & 36.24 & 15.99 & ND & ND \\
\hline 5 & 6.23 & 223.50 & 24.04 & 33.06 & 34.92 & 9.25 & 195.70 & 56.63 & 37.87 & 18.08 & 31.99 & ND & ND \\
\hline 6 & 6.43 & 103.60 & 19.23 & 24.31 & 21.94 & 13.02 & 147.78 & 103.71 & 33.24 & 6.02 & 25.99 & ND & ND \\
\hline 7 & 6.69 & 176.90 & 28.85 & 3.890 & 5.735 & 8.00 & 88.09 & 88.88 & 46.08 & 44.16 & 35.98 & ND & ND \\
\hline 8 & 6.32 & 141.00 & 19.23 & 17.50 & 12.22 & 6.32 & 119.87 & 144.1 & 51.6 & 25.09 & 17.99 & ND & ND \\
\hline 9 & 6.31 & 168.00 & 16.03 & 12.64 & 20.32 & 16.78 & 91.91 & 111.11 & 120.8 & 18.07 & 11.99 & ND & ND \\
\hline 10 & 6.25 & 177.20 & 14.42 & 26.26 & 13.43 & 4.65 & 143.73 & 124.26 & 40.47 & 33.04 & 47.98 & ND & ND \\
\hline 11 & 7.10 & 196.40 & 9.619 & 34.04 & 17.49 & 5.91 & 163.61 & 102.80 & 30.86 & 13.04 & 11.99 & ND & ND \\
\hline
\end{tabular}

$\mathrm{ND}=$ Not detectible $\left(<0.0001 \mathrm{mgL}^{-1}\right)$

Table 5. Suitability of groundwater for livestock consumption based on Ayers and Westcot (1985) and USEPA (1975).

\begin{tabular}{|c|c|c|c|c|c|c|c|c|c|c|c|c|c|c|c|c|c|c|}
\hline \multirow{2}{*}{$\begin{array}{l}\text { SL } \\
\text { NO. }\end{array}$} & \multicolumn{2}{|c|}{ TDS } & \multicolumn{2}{|c|}{$\mathbf{H}_{\mathrm{T}}$} & \multicolumn{2}{|c|}{$\mathbf{F e}$} & \multicolumn{2}{|c|}{ Mn } & \multicolumn{2}{|c|}{$\mathbf{Z n}$} & \multicolumn{2}{|c|}{ Cl } & \multicolumn{2}{|c|}{ B } & \multicolumn{2}{|c|}{$\mathbf{C u}$} & \multicolumn{2}{|c|}{ As } \\
\hline & Pond & $\begin{array}{l}\text { Tube- } \\
\text { well }\end{array}$ & Pond & $\begin{array}{l}\text { Tube- } \\
\text { well }\end{array}$ & Pond & $\begin{array}{l}\text { Tube- } \\
\text { well }\end{array}$ & Pond & $\begin{array}{l}\text { Tube- } \\
\text { well }\end{array}$ & Pond & $\begin{array}{l}\text { Tube- } \\
\text { well }\end{array}$ & Pond & $\begin{array}{l}\text { Tube- } \\
\text { well }\end{array}$ & Pond & $\begin{array}{l}\text { Tube- } \\
\text { well }\end{array}$ & Pond & $\begin{array}{l}\text { Tube- } \\
\text { well }\end{array}$ & Pond & $\begin{array}{l}\text { Tube- } \\
\text { well }\end{array}$ \\
\hline 01 & 125.70 & 434.00 & 72.9 & 12.65 & 94.6 & 75.08 & 40.57 & 41.42 & 25.09 & 12.05 & 29.99 & 139.95 & 0.09 & 0.05 & ND & 0.05 & ND & $\mathrm{ND}$ \\
\hline 02 & 198.70 & 366.00 & 128.7 & 7.99 & 101.25 & 154.22 & 56.29 & 45.07 & 17.08 & 12.05 & 27.99 & 105.96 & 0.11 & 0.16 & ND & ND & ND & ND \\
\hline 03 & 135.90 & 350.00 & 125.8 & 12.46 & 77.34 & 87.5 & 44.78 & 40.47 & 17.08 & 23.06 & 63.98 & 115.96 & 0.18 & 0.05 & ND & ND & ND & ND \\
\hline 04 & 121.90 & 475.00 & 52.36 & 10.22 & 112.12 & 111.11 & 55.29 & 33.43 & 36.24 & 12.05 & 15.99 & 109.96 & 0.06 & ND & ND & 0.02 & ND & ND \\
\hline 05 & 223.50 & 377.00 & 118.0 & 9.31 & 56.63 & 87.5 & 37.87 & 45.04 & 18.08 & 24.10 & 31.99 & 105.96 & 0.03 & 0.09 & ND & ND & ND & ND \\
\hline 06 & 103.60 & 321.00 & 143.6 & 11.45 & 103.71 & 87.5 & 33.24 & 40.47 & 6.02 & 44.10 & 25.99 & 101.96 & ND & 0.14 & ND & ND & ND & ND \\
\hline 07 & 176.90 & 434.00 & 158.0 & 9.38 & 88.88 & 88.34 & 46.08 & 35.85 & 44.16 & 20.02 & 35.98 & 111.96 & 0.08 & 0.12 & ND & 0.02 & ND & ND \\
\hline 08 & 141.00 & 391.00 & 137.5 & 10.36 & 144.1 & 81.1 & 51.6 & 40.46 & 25.09 & 6.02 & 17.99 & 109.96 & 0.11 & ND & ND & ND & ND & ND \\
\hline 09 & 168.00 & 388.00 & 177.0 & 5.05 & 111.11 & 88.87 & 120.8 & 46.78 & 18.07 & 24.06 & 11.99 & 115.96 & 0.14 & 0.13 & ND & ND & ND & ND \\
\hline 10 & 177.20 & 367.00 & 109.6 & 8.81 & 124.26 & 97.7 & 40.47 & 36.86 & 33.04 & 18.07 & 47.98 & 171.94 & ND & 0.03 & ND & ND & ND & ND \\
\hline 11 & 196.40 & 390.00 & 131.6 & 4.41 & 102.8 & 100.45 & 30.86 & 40.47 & 13.04 & 18.07 & 11.99 & 95.97 & 0.03 & ND & ND & 0.03 & ND & ND \\
\hline
\end{tabular}

Keys: $\mathrm{ND}=$ Not detectible $\left(<0.0001 \mathrm{mgL}^{-1}\right)$ 


\section{Conclusions}

Within this research program, the study was carried out to evaluate the chemical constituents and the suitability of water samples of Barisal upazila. The samples were slightly acidic in nature and 07 pond water were not suitable for aquaculture in respect of $\mathrm{pH}$. EC delineated that all the samples of pond were rated as "low salinity" and groundwaters were "medium salinity" $(\mathrm{C} 2)$ class for irrigation although two samples of groundwater are High salinity group (C3). All samples of pond were "excellent" and all the groundwaters were "good" for irrigation except two high salinity group water. In respect of TDS the samples were "highest desirable" limit for drinking and "fresh water" for irrigation and also suitable for aquaculture and livestock. Calcium shows that the samples were "maximum permissible" class for drinking and 1 sample was "maximum permissible" in respect of Mg. Calcium indicate the samples were suitable for aquaculture but 7 samples (No. 2, 3, 5, 6, 8, 10 and 11) were not suitable due to higher $\mathrm{Mg}$ content. Sodium of the samples was within the safe limit for multipurpose use. In respect of K, 09 samples were unsuitable for aquaculture and all of the water samples exceeded the irrigation recommendation limit. The waters of the study area were within safe limits and suitable for drinking, irrigation, aquaculture and livestock consumption in respect of $\mathrm{Cu} . \mathrm{Cl}$ showed the samples were unsuitable for livestock consumption except 7 ponds water (No. 1, 2, 4, 6, 8, 9 and 11) were suitable and the rest are not suitable for aquaculture. The samples were not suitable for aquaculture but suitable for drinking, irrigation and livestock consumption in respect of Fe. Manganese indicated that 1 sample (No. 9) was not suitable for drinking and livestock consumption and all are not suitable for aquaculture but suitable for irrigation. Not suitable result was found in $\mathrm{Zn}$ for aquaculture but significant result was found for drinking, irrigation and livestock consumption. All samples were "excellent" for sensitive, semi-tolerant and tolerant crops in respect of B. None of the samples were responded to $\mathrm{CO}_{3}$ test and $\mathrm{HCO}_{3}$ concentrations were found almost at normal level. All the water sources were free from As contamination. The present investigation showed that the $\mathrm{P}$ concentration in groundwater sources of Barisal upazila might not be harmful for multipurpose use. Sodium absorption ratio categorized the samples "excellent" class for irrigation except 2 groundwater samples (sample no. 5 and 6). Among 22 samples(pond + tube-well) of both pond and tube-well SSP rated 6 samples as "excellent" 15 were "good" and 01 as "permissible" for irrigation, 15 samples were "suitable", 03 were "marginal" and 04 were "unsuitable" for irrigation. With respect to $\mathrm{H}_{\mathrm{T}}$, out of 22 samples (pond + tube-well) 13 were "moderately hard" and 09 were "hard" limit for irrigation and the samples were suitable for livestock consumption.

\section{Conflict of interest}

None to declare.

\section{References}

APHA (American Public Health Association), 2005. Standard Methods for the Examination of Water and Wastewater. $21^{\text {th }}$ edition, AWWA and WEF, Washington, USA. 1-30 40-175.

APHA. 1995. Standard Methods for the Examination of Water and Wastewater. 19th edn. American Public Health Association. Wahsington, D.C. 20005.

Ayers RS and DW Westcot, 1985. Water Quality for Agriculture. FAO Irrigation and Drainage Paper. 29: 1144.

Azad AK, 2003. Impacts of Farakka barrage on surface water resources in Bangladesh. World Environment Day 5 June 2003. Report, Dept. Env., The Government of Bangladesh. pp. 40-43.

Berner EK and RA Berner, 1987. The Global Water Cycle: Geochemistry and Environment. Prentice-Hall, Englewood Cliffs, 387 pages.

Davis SN and RJMD Wiest, 1966. Hydrology, John Wiley and Sons, Inc. New York. 263p.

Eaton AD, LS Clesceri and AE Greenberg, 1995. Standard methods for the Examination of water and wastewater. 19th edn. American Public Health Association. American Water Works Association, Water Environmental Federation. Washington, D.C. 200005. 1-88 to 1-19.

Freeze AR and JA Cherry, 1979. Groundwater. Prentice Hall Inc., Englewood Cliffs, New Jersey, USA. 84-387.

Ghosh AB, JC Bajaj, R Hasan and D Singh, 1983. Soil and Water Testing Methods. Laboratory Manual, Div. Soil Sci. Agric. Chem., IARI, New Delhi, India. 1-48.

Gomez KA and AA Gomez, 1984. Statistical Procedures for Agricultural Research. $2^{\text {nd }}$ edn., A WileyInterscience Publication, New York, USA. 442-443.

Hunt DTE and AL Wilson, 1986. The Chemical Analysis of Water: General Principles and Techniques. $2^{\text {nd }}$ edn. the Royal Society of Chemistry, Cambridge. 1-2.

Karanth KR, 1994. Ground Water Assessment Development and Management. Tata McGraw-Hill Publishing Company Ltd, New Delhi, India. pp. 248- 250. 
Llyod R, 1992. Pollution and Freshwater Fish. Published by Fishing News Books, UK.

Meade JW, 1989. Aquaculture Management. New York. Van Nostrand Reinhold.

Michael AM, 1997. Irrigation: Theory and Practices. Vikas Publishing House Pvt. Ltd. New Delhi. 448452 708-717.

Mishra RD and M Ahmed,1993. Manual on Irrigation Agronomy. Oxford and IBH Publishing Co. Pvt. Ltd. New Delhi.

Page AL, RH Miller and DR Keeney,1982. Methods of Soil Analysis. Part-2. Chemical and microbiological properties. Second edition. American Society of Agronomy, Inc. Soil Science Society of American Inc. Madison, Wisconsin, USA. 403-430.

Population Census of Bangladesh, 2001. Bangladesh Bureau of Statistics (BBS).

Raghunath HM, 1987. Groundwater. 2nd edn. Wiley Eastern Ltd. New Delhi. 344-369.

Richards LA, 1968. Diagnosis and Improvement of Saline and Alkali Soils. USDA and IBH. Publishing Co. Ltd. New Delhi, India. 98-99.

Singh AK, MK Mahato, B Neogi and KK Singh,2010. Quality assessment of mine water in the Raniganj coalfield area, India. Mine Water and the Environment, 29: 248-262.

Singh AK, GC Mondal, S Kumar, TB Singh, BK Tewary, and A Sinha, 2009. Major ion chemistry, weathering processes and water quality assessment in upper catchment of Damodar River basin, India. Environmental Geology, 54: 745-758.

Tandon, H. L. S. 1995. Methods of Analysis of Soils, Plants, Waters and Fertilizers. Fertilizer Development and Consultation Organization, New Delhi, India. 84-90.

Todd DK, 1980. Groundwater Hydrology. $2^{\text {nd }}$ edn., John Wiley and Sons. Inc., New York, USA. 267-315.

U.S. Environmental Protection Agency, 1975. Federal Register. 40: 59566-59588.

WHO (World Health Organization), 1971. International Standards for Drinking Water. Cited from Ground water Assessment Development and Management. 248-249.

Wilcox LV, 1955. Classification and use of irrigation water. U.S Depart. of Agric. Cir. No. 969. Washington, USA. 19 